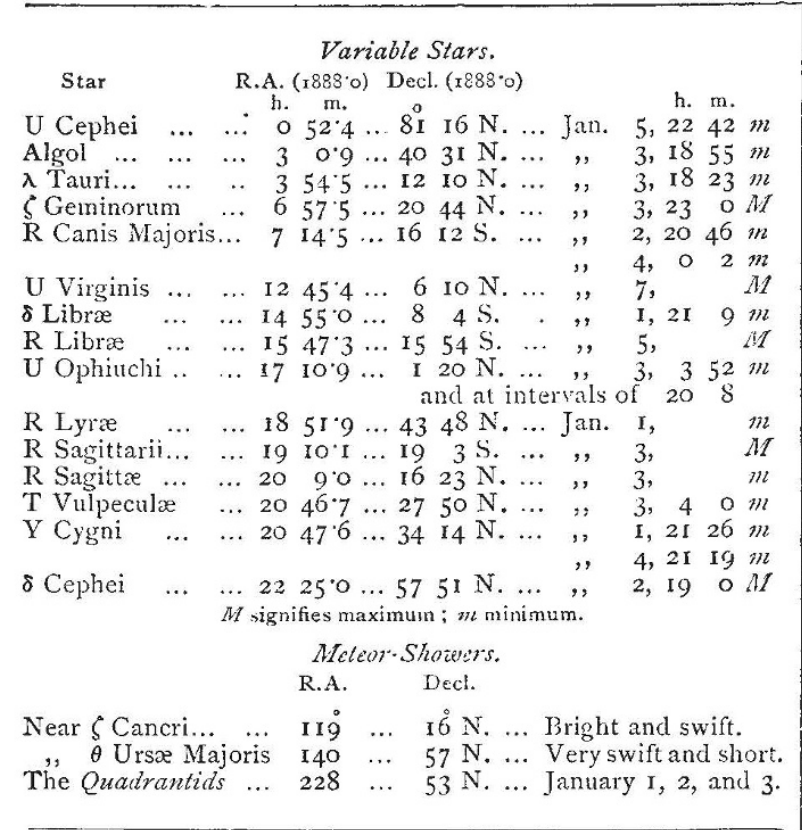

\section{GEOGKAPHICAL NOTES.}

THE two great medals of the Paris Geographical Society have been awarded to General Alexis de Tillo for his great topographical work on Europe and Asia, and to M. Alphaud, Inspector General of the Ponts et Chausées, who, "by inspiring a feeling for the benutiful and of the necessities of hygiene, has done so mucls to improve the topography of the capital." Medals of the first class were awarded to M. Enguehard, geographical draughtsman; Prof. Francois Bazin; Prof. Maxime Mabire; Prif. Paul Gaffarel, for a work on the soil of France M. Fauve, for his fine topographical works; M. Ch. Lasalle, for a work on the defences of France; M. Pierre Collet, for his relief plans; Lieut. Somprou; M. Poinet; and M. Verragen.

LIEUT. VON FRANCOIS and Dr. Wolf will start shortly on a scientific mission to Togoland, one of the German possessions on the West Coast of Africa.

Is the new part of the Joumal of the Manchester Geographical Society there is an instructive paper by the Rev. R. P. Ashe on Uganda, and the manners and customs of its people.

News from Africa states that the well-known African traveller, Ierr Gottlob Adolf Kratuse, has returned to Accra on the Gold Coast. In May 1886 he commenced his exploring expedition. Starting from Accra and crossing the River Acropang. Volta at Kpang, he proceeded in an easterly direction, passing through Kpando, Krahje, Salaga, Dagomba, Walawala, East Gurunsi, and Busanga to Wagaduga ard Ban 1)jagara, penetrating to within a few miles of Timbuctoo. On his return he journeyed through West Gurunsi, the Ashantee District, Kintimso, Salaga, Sogede, Baleta, Gheshi, Atakpama, and Pla. Lieut. Kund on his journey to Cameroon met Herr Krause at Accra, and sends this report. Herr Krause states that to the north of Salaga the influence of the Sahara is most prominent, and the country is more desolate the further north one goes. Rice and tobacco are universally cultivated. The principal articles of commerce are kola-nuts and salt, the district being chiefly inhabited by the Fula tribe. Nearer to the coast there are several other tribes and dialects, but the Haussa language is most generally spoken. Most of the population is still heathen, but some of the merchants and beiter educated families are Mohammedans. Herr Krause was not enabled to proceed as far as Timbuctoo, owing to the unfriendliness of the Sheikh Tidchani.

THE Bollettino of the Italian Geographical Society for October and November publishes a valuable paper by Sig. A. Borda on the geography, history, and present social conditions of the Republic of Columbia (New Grenada), which promises to enter on an era of peace and prosperity under its enlightened and popular President Nunez, who was elected last June for a term of six years. The present population is calculated on official returns at about four millions, including 200,000 stil living in the tribal state in the more inaccessible forest regions. These forests are described as abounding in a great variety of valuable trees yielding the finest cabinet woods, balsams, gums, dyewoods, alimentary and medicinal products. The flora and fauna are scarcely exceeded by those of any other land in diversity of types, while the country contains vast supplies of minerals, such as gold, silver, platina, rubies, emeralds, crystals, porphyry, salt, and sulphur. Since the conquest till the present time the yield of the precious metals is estimated at $f 130,000,000$, mined chiefly in the departments of Canea and Antioquia. Mining operations, which had suffered much from the unsettled state of the country, have recently received a fresh stimulus by the introduction of foreign capital and improved engineering appliances. The metalliferous districts, which occur at various elevations, and especially along the river valleys, are stated to be generally salubrious, and foreigners are now enabled to purchase mines on the same terms as the natives. But the great natural resources of Columbia still lie almost untouched, chiefly through the lack of good and regular communications, the roads being generally impracticable for wheeled traffic, while the railway system is little developed. Besides the Panama, Bolivar, and Cucuta lines already open, others are in course of construction in the departments of Canea, Antioquia, Cundinamasca, Tolima, and Santander. The great water highway of the Maddalena has a fleet of twenty-five steamers, and is connected with the seaport of Cartagena by the Digue, a navigable canal branching off at Calamar. The yearly imports from Europe and the United States average $£ 3,000,000$, and the exports $£ \mathrm{I}, 600,000$. The revenue for 1887-88 is estimated at $f 4,000,000$, the expenditure $\delta 4,600,000$, and the public debt $£ 4,500,000$, half internal and half foreign. The Government has still at its disposal extensive domains, which are granted on favourable terms to immigrants as well as to native and foreign speculators. $\Lambda$ present the country is in the enjoyment of profound peace, with improved external and internal relations, and a general clesire to close once for all the era of aimless political revolutions.

\section{JOURNAL OF THE ROYAL AGRICULTURAL SOCIETY. ${ }^{1}$}

THE most recent number of this Journal well keeps up the credit of its predecessors in spite of the grievous loss the Society sustained a year ago in the death of its talented editor, Mr. H. M. Jenkins. The contributors include the Earl of Coventry, Sir F. Bramwell, F. R.S., Drs. J. Voelcker and P. Vieth, Major Craigie, Principal W. Robertson of the Royal Veterinary College, Mr. James Macdonald, of Edinburgh, Messis. Bernard Dyer, Albert Pell, Charles Whitehead, William C. Little, Charles Clay, Ilerbert J. Little, and others. Since these remarks were penned, we regret to hear of the sudden death of Principal Robertson, of the Royal Veterinary College.

The contents may be classified as--strictly agricultural, comprising articles on ensilage, sheep-feeding experiments, and reports on the prize-farm competitions in Northumberland; statistical, as presented in papers upon twenty years' changes in our foreign meat supply ; engineering, as represented in trials of portable engines, and report of the consulting engineers at New. castle ; and purely scientific, as in papers on micro-organisms and their action on milk and milk products, on protective inoculation for anthrax and quarter ill, and on the progress of the Hessian Hy.

Few of the papers possess such a wide general interest, both scientific and sanitary, as that of Dr. P. Vieth, on the action of micro-organisms on milk. Milk is subject to lactic fermentation, caused by the presence of a bacillus, consisting of short motionless rods propagating by segmentation. The effect of these bacilli is to cause the milk to sour and lose its liquid character, and assume the appearance of a gelatinous mass. The milk, in fact, "turns," and a separation of the curd from the whey follows, as though rennet had been added, but from a different cause. It is also now shown that lactic fermentation requires to be induced by the introduction of bacilli from without, after the milk is drawn from the cow, and that it is not inherent I "Journal of the Royal Agricultural Society," Series II. vol, xxiii. Part II., r887. (John Murray, Albemarle Street.) 